\title{
Capability of Farmers Adaptation towards Natural Resources Vulnerability in Wajak, Malang
}

\author{
Medea Rahmadhani Utomo ${ }^{1}$, Kliwon Hidayat ${ }^{2}$, Setyo Yuli Handono ${ }^{3}$
}

\begin{abstract}
Extreme climate is at risk of a water resource crisis. Land degradation provides challenges for farmers to switch to non-agriculture or not worked on. In cases that occur, then several problems arise including 1) how the internal conditions of the socio-ecological farmers, 2) adaptation of farmers to the crisis of water resources and 3) the role of non-agricultural work in overcoming economic uncertainty. Issues relating to the Socio Ecology System (SES) were examined by mixed methods. It is known, the type of soil on land generally is inceptisol. Mixed cropping system between cassava and cane was chosen to anticipate the loss of farmers, especially when water is difficult. The vulnerability of natural resources encourages farmers to behave creatively and adaptively in carrying out their life activities. The form of adaptation ability of farmers is to utilize the potential of dairy cattle and goat farming when agricultural land is difficult to cultivate. For those who do not have livestock, they take jobs as miners of sand and wood. Sand and wood as future savings. Various non-agricultural activities are able to support many farmers, especially for those who experience a natural resource crisis.
\end{abstract}

Keywords: Adaptation Capability, Natural Resources, Ecological Vulnerability, Socioecology.

\section{INTRODUCTION}

Rich global biodiversity is a source of various ecological resources and services to human beings [1]. One of the rural areas classified as ecologically vulnerable is characterized by the occurrence of dry land due to long drought and limited water resources. Although this perspective provides a mechanism for linking actors in distal places, it is still limited as it ignores the larger social, political, and ecosystem context in which agricultural production, processing, and distribution takes place [2].

Exploring from cases in other countries by [3] Destruction of economy and agriculture (Zimbabwe). Bad management in natural catastrophies (Burma/Myanmar) • The disappearance of the Aral Sea (Uzbekistan) Thought of [4]The sudden run of collectors to the yarshagumba collection sites led to conflicts about access and uncontrolled usage of the resource.

${ }^{1}$ Medea Rahmadhani Utomo, Socio-economic Departement, Faculty of Agriculture, Brawijaya University, Malang,email: medea @ub.ac.id

${ }^{2}$ Kliwon Hidayat, Socio-economic Departement, Faculty of Agriculture, Brawijaya University, Malang, email:

3 Setyo Yuli Handono, Socio-economic Departement, Faculty of Agriculture, Brawijaya University, Malang, email:
Being a minimum requirement, social sustainability is not about ensuring that everyone's needs are met. Barriers can be something obvious: dangerous or exploitive work arrangements, or failing to provide proper safety equipment for workers, but they can also include the structures [5]. Are not always seen as sustainable in a biophysical environmental sense, thus there is a great deal of potential for conflict to occur [6]

According to [7] There was a gradual awakening and awareness of the significance of environmental degradation and the impact of humans on the environment. Several seminal events were held in order to impose some limitations in this regard

Based on classic statements [8]Second, it illustrates that it is communities of the poor and marginalized that face living with the greatest threats to health and livelihood from natural disaster, as well as having to cope with everyday risks from living and working in hazardous environments.

According to [9] the most extreme criticism is that sustainable development, when defined vaguely in order to meet the needs of all stakeholders. The ecosystem along with sprawling landscape and large meadows provides critical habitat for unique biodiversity and natural beauty and harbors many endemic, threatened and ethnobotanically useful medicinal plants [10]

Such partial approaches are less useful in the current situation wherein the capacity ofmany ecosystems to generate resources and ecosystem ser- vices for societal development has become vulnerable to change and no longer can be taken for granted [11].

More recently, resilience has also come to include transformability, the capacity to create a funda- mentally new system when the existing system has become unsustainable [12]. Another worrying condition is that the population continues to increase and inappropriate management can trigger threats and risks for natural resources

Environmental studies im- ply looking at how meaning emerges from our transactions with the environment, always taking into account that these transactions are not un-mediated. [13] This is precisely the triadic unit that the Social Representations Theory (SRT) has been arguing and on the basis of which we shall concentrate our analysis.

To overcome the danger of natural risks it is important to understand the level of rural adaptation (social-ecologies) in this region whose emphasis includes 
1) how the internal conditions of the socio-ecological farmers, 2) adaptation of farmers to the crisis of water resources and 3) the role of non-agricultural work in overcoming economic uncertainty.

\section{RESEARCH METHOD}

The research approach that will be used is a combined approach or a mixed method between qualitative and quantitative. This approach was chosen to gain a complete understanding of the problem of socio-ecological system resilience. The socio-ecological system problem is complex and relates to aspects of vulnerability, livelihood assets, sustainability (ecological, social and economic) and so forth.

The technique of determining informants is using purposive sampling. This technique is used because there are special criteria in determining informants. These criteria include villagers involved in agricultural production activities, villagers involved in social activities, sand mining and dairy farming.

Data collection techniques include observation, indepth interviews, and documentation studies. Observation is needed to find out the various risks of physical damage related to ecological vulnerability. In-depth interviews are needed to explore various patterns of activity of farmers who have the potential to support or who tend to pose risks to natural resources.

Whereas for Data Analysis using miles and hubermans interactive models focused on qualitative descriptive. This analysis technique is needed to provide the depth of data obtained.

\section{RESULTS AND DISCUSSION}

\section{A. Geophysical Condition of Bambang Village}

The area of Bambang Village is 1,761 Ha which is divided into a number of uses such as residential land of 89 ha, agricultural land (fields / fields) of 212 ha, community plantations of 53 ha, forests of 1,396 ha.

Soil fertility conditions can be mapped which includes very fertile $265 \mathrm{Ha}$, fertile 1,246 $\mathrm{Ha}$, while $214 \mathrm{Ha}$, not fertile $36 \mathrm{Ha}$. From these data, soil conditions tend to be fertile. One of the existing crops is crops and food crops such as peanuts, long beans, corn, cassava, taro, sweet potatoes, and sugar cane.

The dominant plants are maize, cassava and sugar cane, which plants can survive in dry soil conditions or soil conditions that are difficult to source water. As for fruit crops such as avocados, papaya, and bananas are also able to be an alternative source of income (income)

From the overall yields and planting area for palawija plants, a land area of $213 \mathrm{Ha}$ was obtained and for production it reached 5327 tons / year. The highest production is obtained from sugar cane, reaching 4335 tons per year. In addition to sugar cane there is corn with a production of 850 tons per year. Followed by cassava plants production reaches 105 tons per year.

For fruit production, which is relatively high is the banana which reaches 112 tons per year. For the widest area of plantations and yards is the allocation of avocado land that is 15 hectares. The most popular type of medicinal plant in Bambang Village is turmeric. The area of land provided to grow $0.25 \mathrm{Ha}$ turmeric is scattered in Bambang Village.

In the field of animal husbandry there are free-range chicken, dairy cows, and goats have a large population. For free-range chicken reaches 7782 tails. On the other hand there are also many dairy cows which are 521 and there are 819 sheep.

Of each businessperson in Bambang Village, 929 people are dominated by the free-range chicken business. The second largest is the business of goat livestock reaching 292 people.

\section{B. Characteristics of Respondents}

The average age of respondents is still relatively productive that is 30 until 55 years. As for their average education is an elementary school Sekolah Dasar (SD), on average they work as farmers and ranchers, the rest are there, sand miners, and housewives.

From the data of respondents there are $38 \%$ work as farmers, $46 \%$ work as farmers and ranchers, and $15 \%$ as sand miners. The people of Bambang Village who applied terraced techniques on the main land were $38 \%$. With regard to water sources, almost everything that is managed depends on rain.

The combination used is usually 1) corn with grass, 2) corn with vegetables and 3) corn with eggplant. They appear to be more dominant using a 54\% monoculture system. For those who use a monoculture planting system, plants cultivated include tomatoes, chilies, sengon, corn, cloves, coffee and cassava.

The agroforestry system is also applied, usually there is a combination of plants 1) sengon and corn, 2) sengon, avocado and corn, and 3) sengon and elephant grass.

\section{Socio-ecologycal Conditions of Farmer's Local traditions of residents during planting}

Planting uses a mixed planting system. Technically, the edges of the land are cassava, the middle is planted with maize, and for sengon it is also planted inside but with a distance apart. The villagers hope that the presence of sengon functions to shade the plants under the stand.

In addition, sengon also provides a function as a reinforcing plant that is able to minimize the occurrence of erosion and landslides. Other annual crops can be used as an alternative to household income when there are no annual crops such as chili or eggplant that can be harvested.

\section{Community Culture in Social Activities}

Some sand soil needs to be kept in their own land for the savings of their children and grandchildren. If sand mining resources continue to be utilized in a fast period of time, then some assets will not be saved except for those who have livestock assets.

Social activities include community service, community service, terracing, routine recitation of Islamic pilgrimage. The community service includes joint efforts in renovating houses, repairing roads, renovating mosque, cleaning land from rubbish and other disturbances, and physical improvement of land. 
Physical damage to the land that is common is clogged drains, irrigation channels and changes in shape of beds. As for the problems in the structure of the land so that emergency to be repaired immediately. Of course all repairs are carried out collectively and citizens' solidarity.

As for certain rituals for the safety of businesses in agriculture. There used to be a certain mantra by carrying coconut husk sepet and menyan, with the hope for safety of the land until harvest. As the times grew, ritual methods containing mystical elements began to fade, in order to anticipate the unpreparedness of the next generation.

\section{E. Land Authorization}

Almost all residents of Desa Bambang have none of the land leases, instead there are residents who rent out to other hamlets. Nearly all agricultural land in Bambang's hamlet is his own.

Residents of Bambang Village consider how to rent land as an additional burden. They choose to work on small plants that can be harvested at any time for their own consumption. Those who have the majority of land with minimal water resources are trying not to be commercialized planting.

Commonly used profit sharing system is maro with a percentage of 50: 50 and mrapat with a percentage of 75: 25 . If maro and mrapat are considered unfavorable to one or both parties then a proportional revenue sharing system becomes an alternative choice.

Proportionary sharing system is a system of distribution of yields in the form of goods or money adjusted to the amount of expenditure of both parties. If the land owner spends $40 \%$ of the production cost and the cultivator spends $60 \%$ of the production cost, then it is similar to the harvest or transaction money received.

\section{F. Use of Labor}

The average daily wage for laborers is Rp. 20000, counting from 6:00 a.m. to 12:00 p.m. This nominal value tends to be low, so it is not surprising that many Bambang villagers have shifted to the city to access livelihoods as construction workers and factory workers in the city and around Malang Regency.

Regarding local workforce in farming, local residents of Bambang Village sometimes still use a splice system that emphasizes the principles of tolerance and solidarity. But the splice system is not measured by workload and without calculating the length of work.

All activities which are of help to take place on the basis of each awareness without the element of commercialization or even transactional. Transactional principles are only commonly used in sand mining and logging activities which are included in external activities

\section{G. Marketing of Agricultural Products}

Apart from agricultural commodities, livestock commodities are one of the marketable products, especially when there are no agricultural products that can be sold. When the land is dry due to the long dry season, the livestock business starting from dairy cows, beef cattle, beef chickens becomes the main employment choice to be occupied.
Besides vegetables and livestock products, farmers also use sengon wood as an economic source. For sale of sengon 1 truck, it can load 8 tons, if it is converted to almost Rp. 4000000. This value is quite high, especially for family expenses, school fees and unexpected household costs.

\section{H. Community Response (Local strengths) in facing ecological vulnerability}

When people are confronted with critical natural resources, creative ideas will emerge to look for other employment opportunities for survival. In the dry season residents of Bambang Village tend not to carry out activities on agricultural land.

Work in the field of livestock is one way when not working on agricultural land. Livestock as an alternative source of income that can sustain the economy when they do not get income from agriculture.

Erosion and landslides have occurred about two decades ago. The incident prompted Bambang Village residents to continue to improve to minimize the existing disasters. One effort that can be done to overcome erosion and landslides is to make terraces on sloping land.

\section{H. Efforts to Anticipate the Dry Season}

Planting cassava or sengon, is used as their anticipation when the dry season comes. These plants are not too dependent on water. In addition to cassava and sengon they also cultivate plants that are not dependent on water such as elephant grass and sugar cane.

Farmers' efforts in handling pests and diseases still use traditional methods. Pests that are said to embuk can kill some plants such as corn, potatoes, tomatoes that attack the leaves to the roots. The way to overcome this is to turn off directly without pesticides or using pesticides

Seeds that tend to be expensive, such as potato and corn seeds, are usually done by seeding independently with it, so do not depend on the seed seller. Farmers are increasingly aware that the cost of production, especially seeds, is increasingly expensive and encourages them to produce independently.

\section{$J$. The role of external programs}

External programs that include sand mining, sengon wood management, ecotourism development, and village fund management are alternative economic sources when agricultural work is difficult to manage

\section{Sand Mining Activities}

The average capacity of sand transported is 1 to 2 trucks per day in one mining area. Each truck reaches a capacity of 6 to 8 tons of sand in one mining area. The average income of sand mining workers involved in the individual system is between Rp. 25.000 to Rp. 50.000 per day.

The lowest price of sand per truck reaches between Rp. 500.000 to Rp. 600.000 per truck. While the highest price is between $\mathrm{Rp} 900.000$ to 1.000 .000 per truck. Delivery in a week can be done up to 3 times. One-time delivery the average truck driver net income is Rp. 500.000. 


\section{Annual Crop (sengon) Management Activities}

The income from the sale of sengon wood per harvest is between Rp. 10.000.000 to Rp. 40.000.000. The size of the income is known from the magnitude of the diameter of the tree trunks sold, the number of trees, and the condition of the demand for sengon wood. Sengon labor income between Rp. 100.000 to Rp. 500.000 per day.

\section{Tourism Development Planning}

Tourism development by the Ministry of Environment Kementerian Lingkungan Hidup (KLH) is considered by some residents to be used as ecotourism or a tourist park. There are several impacts from the construction of the tour which includes social impacts, physical impacts, ecological impacts and economic impacts.

\section{CONCLUSION}

The socio-ecological conditions of farmers characterize adaptive agricultural activities in situations of natural resource crises. Utilization of economic resources such as dairy farming, planting sengon, sugar cane, cassava and avocado are considered relevant and adaptive when natural resource vulnerabilities occur

Farmers consider various natural disasters and risks as common. The limited natural resources available encourage farmers to think and act creatively. Social dynamics that occur in Bambang Village are still relatively strong. Social dynamics are marked by the existence of activities of village physical development work, improvement of the ecological environment, and various community gathering activities.

Farmers' adaptation to weather uncertainty and natural resource crises can be overcome by increasing social mobility and collaborative efforts with various external business actors. This mobility can be seen from the efforts of farmers to access work as sand miners, managers of sengom dairy farmers, beef cattle, goats and chickens. Non-agricultural activities such as sand mining serve as an effort to adapt alternative resources when agricultural land is difficult to manage due to limited natural resources

\section{REFERENCE}

[1] S. Chiekooumetsu, Global Environmental Studies SocialEcological Systems in Transition.

[2] X. Eakin, Hallie., Rueda, "Governance Challenges in Telecoupled Food Systems," Ecpr Gen. Conf. Sess. 262, 2013.

[3] N. Verma, "Political and economic dimensions of sustainable development," World Aff., vol. 12, no. 2, pp. 164-171, 2008.

[4] K. Thapa et al., "Linkages among forest, water, and wildlife: a case study from Kalapani community forest in the Lamahi bottleneck area of Terai Arc Landscape," Int. J. Commons, vol. 12, no. 2, pp. xx-xx, 2018.

[5] A. Benaim, A. C. Collins, and L. Raftis, "The Social Dimension of Sustainable Development : Guidance and Application Abstract :," Technology, 2008.

[6] S. Vallance, H. C. Perkins, and J. E. Dixon, "What is social sustainability? A clarification of concepts," Geoforum, vol. 42, no. 3, pp. 342-348, 2011.

[7] A. H. Rasouli and D. A. Kumarasuriyar, "The Social Dimention of Sustainability: Towards Some Definitions and Analysis," $J$. Soc. Sci. Policy Implic., vol. 4, no. 2, pp. 23-34, 2016.

[8] R. J. H. Clark, M. L. Greenfield, and R. S. Nyholm, Complexes of the early transition-metal halides with tritertiary arsines. 1966.
[9] S. McKenzie, "Working Paper Series No 27 SOCIAL SUSTAINABILITY : TOWARDS SOME DEFINITIONS University of South Australia," Univ. South Aust., no. 27, pp. 131, 2004.

[10] R. M. Kunwar and R. R. Parajuli, "Good governance in natural resource management: a case study from Dolpa district, Nepal," Banko Janakari, vol. 17, no. 1, pp. 17-24, 1970.

[11] C. Folke, T. Hahn, P. Olsson, and J. Norberg, "Adaptive Governance of Social-Ecological Systems," Annu. Rev. Environ. Resour., vol. 30, no. 1, pp. 441-473, 2005.

[12] J. de Kraker, "Social learning for resilience in social-ecological systems," Curr. Opin. Environ. Sustain., vol. 28, pp. 100-107, 2017.

[13] M.-L. Rouquette, E. Sautkina, P. Castro, M. L. Félonneau, and E. Guillou-Michel, "Social representations theory and environmental studies," Des. Soc. Innov. Planning, Build. Eval., no. January, pp. 109-115, 2005. 